\title{
ANALISIS PERBANDINGAN METODE PROBLEM BASED LEARNING DAN PROBLEM SOLVING UNTUK MENINGKATKAN KEMAMPUAN BERFIKIR KREATIF
}

\author{
Marten Yogaswara', Afief Maula Novendra ${ }^{2}$, Saiful Almujab ${ }^{3}$, \\ Yudho Ramafrizal $\mathrm{S}^{4}$, \\ 1,2,3,4 Pendidikan Ekonomi FKIP Unpas \\ 1yogaswar@unpas.ac.id, 2afiefmaulanovendra@unpas.ac.id,

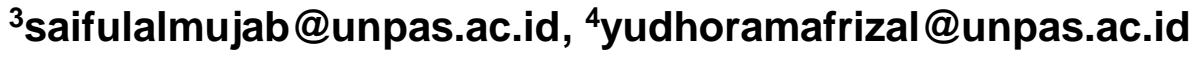

\begin{abstract}
This study aims to determine whether there are differences in students' creative thinking abilities between classes using the Problem Based Learning method and classes that use the Problem Solving learning method. In this study a quasiexperimental design method is used, which is a type of experiment that uses all intact groups to be treated. The quasi-experimental design (quasi-experimental) used in this study is counterbalanced design. In Counterbalanced Design, it uses two classes in which all classes are experimental classes. The difference is located in sub-topics or basic competencies that are carried out in each class with different treatments. Counter balanced Design research design does not use pretest but in this design, students are only given a posttest as a benchmark of learning success. The results of the study concluded that the application of the problem based learning method was more effective in increasing students' creative thinking abilities compared to the problem solving and project based learning method.
\end{abstract}

Keyword: Problem Based Learning, Problem Solving, Creative thimking

\section{ABSTRAK}

Penelitian ini bertujuan untuk mengetahui terdapat perbedaan kemampuan berpikir kreatif siswa antara kelas yang menggunakan metode pembelajaran Problem Based Learning dengan kelas yang menggunakan metode pembelajaran Problem Solving. Dalam penelitian ini digunakan metode quasi-experimental design (eksperimen semu) yaitu jenis eksperimen yang menggunakan seluruh subjek yang utuh (intact group) untuk diberi perlakuan (treatment). Bentuk quasi eksperimental design (eksperimen semu) yang digunakan dalam penelitian ini adalah Counterbalanced design. Dalam Counterbalanced Design ini menggunakan dua kelas dimana semua kelas merupakan kelas eksperimen. Perbedannya adalah terletak pada sub bahasan atau kompetensi dasar yang dilakukan disetiap kelas dengan berbeda treatment. Desain penelitian Counter balanced Design tidak menggunakan pre test tapi didalam desain ini siswa hanya 
diberi posttest saja sebagai tolak ukur keberhasilan pembelajaran. Hasil penelitian dapat disimpulkan bahwa penerapan metode pembelajaran problem based learning lebih efektif dalam meningkatkan kemampuan berpikir kreatif siswa dibandingkan dengan metode belajar problem solving dan project based learning. Kata Kunci : Problem Based Learning, Problem Solving, Berfikir kreatif

\section{A. Pendahuluan}

Menurut pandangan

konstruktivisme, belajar merupakan suatu proses

pembentukan

pengetahuan. Pembentukan ini harus dilakukan oleh siswa sehingga siswa harus aktif melakukan kegiatan, aktif berpikir, menyusun konsep dan memberi makna tentang hal-hal yang sedang dipelajari, tetapi yang paling menentukan terwujudnya gejala belajar adalah niat belajar siswa itu sendiri. Sementara peranan guru dalam belajar konstruktivistik adalah membantu agar proses pengkonstruksian pengetahuan oleh siswa berjalan lancar. Guru tidak hanya mentransferkan pengetahuan yang telah dimilikinya, melainkan membantu siswa untuk membentuk pengetahuannya sendiri dan dituntut untuk lebih memahami jalan pikiran atau cara pandang siswa dalam belajar. Oleh karena itu, guru memiliki peran sebagai fasilitator dalam proses pembelajaran yang dapat meningkatkan motivasi siswa dalam mengkontruksi suatu konsep yang nantinya akan meningkatkan kemampuan berpikir. Terkait kemampuan berpikir, sekolah ditantang menemukan cara dalam rangka memungkinkan siswa sukses dalam pekerjaan dan kehidupan melalui penguasaan keterampilan berpikir kreatif, pemecahan masalah yang fleksibel, berkolaborasi dan berinovasi (Zubaidah, 2016).

Menurut Purhantara (2012), kreativitas merupakan kemampuan untuk mengembangkan ide-ide baru dan untuk menemukan cara-cara baru dalam melihat masalah dan peluang. Kreativitas akan mengarahkan pada kemampuan untuk memberikan gagasan-gagasan baru dan menerapkannya dalam pemecahan masalah meliputi baik ciri-ciri aptitude seperti kelancaran (fluency), keluwesan (flexibility), dan keaslian (originality) dalam pemikiran, maupun ciri-ciri non aptitude, seperti rasa ingin tahu, senang mengajukan pertanyaan dan selalu ingin mencari pengalaman baru (Filsaime, 2008). Kemampuan berpikir kreatif sangat 
Didaktik : Jurnal IImiah PGSD STKIP Subang, ISSN Cetak : 2477-5673 ISSN Online : 2614-722X Volume V Nomor 2, Desember 2019

diperlukan agar kompetensi sumber daya manusia kita tidak kalah dengan bangsa lain. Sebagaimana diketahui, dasar-dasar berpikir selama ini pada umumnya tidak dikuasai dengan baik oleh siswa. Beberapa hasil penelitian menunjukkan rendahnya kemampuan berpikir yang dimiliki oleh siswa sekolah menengah, mahasiswa S1, bahkan juga mahasiswa S2 (Rofi'uddin, 2018). Hal tersebut juga terlihat dari profil kemampuan siswa Indonesia yang dikeluarkan kemendikbud pada tahun 2017.

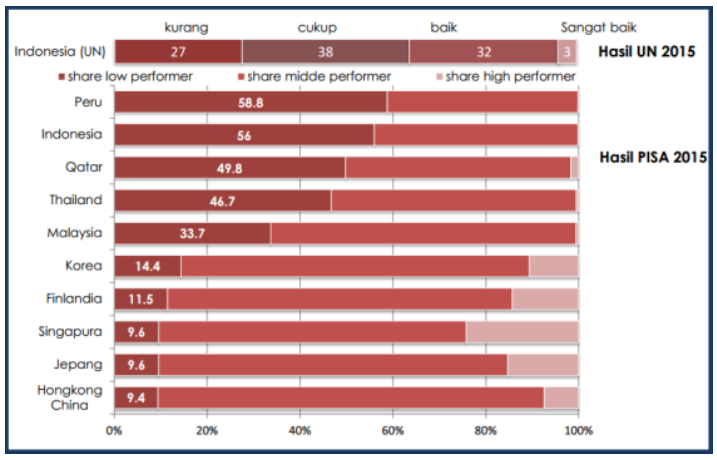

Gambar 1

Validasi: Profil Level kemampuan Siswa Indonesia

Sumber:(Nizam, 2017).

Dari gambar 1.1 disimpulkan bahwa daya kreatifitas masyarakat indonesia masih dalam kategori rendah sehingga jauh tertinggal dari negara-negara lain. Hasil observasi lebih lanjut memperlihatkan bahwa tingkat berpikir kreatif siswa SMKN 3 Bandung masih tergolong rendah yakni sebesar $38,06 \%$.
Tabel 1

Pencapaian Indikator Kemampuan

Berpikir Kreatif Siswa Kelas XI

\begin{tabular}{|c|c|c|c|c|c|}
\hline \multirow{2}{*}{ Kelas } & \multirow{2}{*}{$\begin{array}{l}\text { Jumlah } \\
\text { Siswa }\end{array}$} & \multicolumn{4}{|c|}{$\begin{array}{l}\text { Indikator Kemampuan Berpikir Kreatif } \\
\qquad(\%)\end{array}$} \\
\hline & & $\begin{array}{l}\text { Berpikir } \\
\text { Luwes }\end{array}$ & $\begin{array}{l}\text { Berpikir } \\
\text { Lancar }\end{array}$ & $\begin{array}{l}\text { Berpikir } \\
\text { Orisinal }\end{array}$ & $\begin{array}{l}\text { Berpikir } \\
\text { Terperinci }\end{array}$ \\
\hline $\begin{array}{c}\mathrm{XI} \text { AK } \\
1\end{array}$ & 36 & 41,75 & 40,80 & 32,77 & 38,33 \\
\hline $\begin{array}{c}\mathrm{XI} \text { AK } \\
2\end{array}$ & 36 & 41,80 & 39,33 & 34,50 & 35,20 \\
\hline \multicolumn{2}{|c|}{ Rata-Rata } & 41,775 & 40,065 & 33,635 & 36,765 \\
\hline
\end{tabular}

Sumber : Pra Penelitian, data diolah

Data tabel 1 tersebut menunjukkan tingkat kemampuan berpikir kreatif yang masih rendah. Pola pengembangan kemampuan berpikir kreatif ini tentu harus dimulai dari mengarahkan siswa pada pembelajaran yang berorientasi pada keterampilan berpikir kreatif. Untuk itu, guru harus terampil dalam menggunakan metode-metode pembelajaran yang dapat meningkatkan kemampuan berpikir kreatif siswa. Guru tidak harus selalu menyampaikan materi, tetapi guru harus merangsang pemikiran siswa dengan pertanyaan-pertanyaan yang penuh dengan selidik, memancing penalaran, dan memberikan petunjuk yang merangsang siswa untuk menyimpulkan. Cara inilah yang disebut dengan membangun pengetahuan sendiri (kostruktivisme). Hal tersebut sejalan dengan yang 
Didaktik : Jurnal IImiah PGSD STKIP Subang, ISSN Cetak : 2477-5673 ISSN Online : 2614-722X Volume V Nomor 2, Desember 2019

diungapkan oleh Jean Piaget bahwa pengetahuan tidak diperoleh secara pasif oleh seseorang, melainkan melalui tindakan (action).

Metode-metode pembelajaran yang dapat meningkatkan motivasi siswa agar aktif dalam proses pembelajaran. Saat ini begitu banyak model pembelajaran yang dapat digunakan guru maupun dosen untuk menyampaikan pembelajaran di kelas. Namun terkait dengan peningkatan berpikir peserta didik, peneliti merujuk pada pendapat Dewey dalam Filsaime (2008:9) yang memandang bahwa berpikir kreatif sebagai sebuah pemecahan masalah, sehingga model pembelajaran pambelajaran berbasis masalah merupakan model pembelajaran yang dapat dimanfaatkan sebagai media untuk meningkatan kreatifitas. Model pembelajaran yang menekankan pada masalah yang dapat digunakan adalah problem based learning (PBL) dan Problem Solving (PS) (Lidinillah, 2013). Model pembelajaran problem based learning (PBL) atau dikenal dengan model pembelajaran berbasis masalah merupakan model pembelajaran yang menggunakan permasalahan nyata yang ditemui di lingkungan sebagai dasar untuk memperoleh pengetahuan dan konsep melalui kemampuan memecahkan masalah (Fakhriyah, 2014). Sedangkan Problem solving adalah proses pembelajaran yang menyatukan sekelompok individu untuk menganalisis suatu situasi, menentukan masalah yang sebenarnya, melihat setiap solusi, mengevaluasi setiap solusi, dan memilih yang terbaik untuk tujuan mereka (llleris, 2008). Metode Problem solving mengarahkan peserta didik agar dapat menjadi penemu independen. Fokus dari metode ini bukanlah apa yang harus dipelajari tetapi bagaimana cara belajar (Mahmood, Jumani, \& Arshad, 2015).

Metode pembelajaran berbasis masalah (Problem Based Learning/PBL) merupakan metode pembelajaran yang berpusat pada siswa. PBL menyuguhkan berbagai situasi bermasalah yang autentik dan bermakna kepada siswa, yang berfungsi sebagai batu loncatan untuk investigasi dan penyelidikan. Metode PBL dirancang untuk membantu siswa dalam mengembangkan keterampilan berpikir, keterampilan menyelesaikan 
Didaktik : Jurnal IImiah PGSD STKIP Subang, ISSN Cetak : 2477-5673 ISSN Online : 2614-722X Volume V Nomor 2, Desember 2019

masalah, dan keterampilan intelektualnya, mempelajari peranperan orang dewasa dengan mengalaminya melalui berbagai situasi riil atau situasi yang disimulasikan dan menjadi siswa yang mandiri dan otonom. Dengan demikian, sekolah sebagai tempat dalam kegiatan pembelajaran harus dapat membantu siswa dalam meningkatkan kemampuan intelektual dan mengatasi masalah-masalah yang dihadapi siswa dalam kehidupan nyata. Hal tersebut juga diungkapkan oleh Lang \& Evans (2006:468) bahwa problem based learning is a student centered method in which learners become increasingly independent of the teacher, who suggests educational materials and provides guidance. The taecher's function is to encourage, keep students on track, provide information, and be a fellow learner."

Metode pembelajaran pemecahan masalah (problem solving) merupakan aktivitas pembelajaran yang menekankan pada proses pemecahan masalah yang dihadapi secara ilmiah. Hal tersebut diungkapkan oleh Djamarah \& Zain (2013:103) bahwa metode problem solving (pemecahan masalah) bukan hanya sekadar metode mengajar, tetapi juga merupakan suatu metode berpikir, sebab dalam problem solving dapat menggunakan metode-metode lain yang dimulai dengan mencari data sampai kepada menarik kesimpulan.

Dari uraian yang telah diungkapkan, untuk meningkatkan kemampuan berpikir kreatif siswa, guru harus terampil dalam menggunakan metode pembelajaran Problem Based Learning (PBL) dan metode pembelajaran problem solving. Oleh karena itu, penting kiranya penulis melakukan penelitian tentang apakah terdapat perbedaan kemampuan berpikir kreatif siswa antara kelas yang menggunakan metode pembelajaran Problem Based Learning dengan kelas yang menggunakan metode pembelajaran Problem Solving.

\section{B. Metode Penelitian}

Dalam penelitian ini digunakan metode quasi-experimental design (eksperimen semu) yaitu jenis eksperimen yang menggunakan seluruh subjek yang utuh (intact group) untuk diberi perlakuan (treatment). Bentuk quasi eksperimental design (eksperimen 
Didaktik : Jurnal IImiah PGSD STKIP Subang, ISSN Cetak : 2477-5673 ISSN Online : 2614-722X Volume V Nomor 2, Desember 2019

semu) yang digunakan dalam penelitian ini adalah Counterbalanced design.

Menurut Fraenkel, Wallen, \& Hyun (2011) menyebutkan bahwa: "Quasi experiment design do not include the use of random assignment. Researcher who employ these design rely instead on other techniques to control (or at least reduce) threats to intenal validity."

\section{Desain Penelitian}

Desain penelitian adalah suatu yang berkaitan dengan metode dan alasan mengapa metode tersebut digunakan dalam penelitian (Sugiyono, 2017:205). Metode Quasi Exsperimental Dseign (eksperimen semu) yaitu jenis eksperimen yang menggunakan seluruh subjek yang utuh (intack Gruop) untuk diberi perlakuan (treatment) untuk Quasi Exsperimental Dseign (eksperimen semu) yang digunakan dalam penelitian ini adalah Counterbalanced Design. Desain dalam penelitian ini bila dibuat bagan sebagai berikut:
Tabel 2

Counterbalanced Design

\begin{tabular}{|c|c|c|c|c|}
\hline $\begin{array}{c}\text { Kelas XI OTKP } \\
1\end{array}$ & $X_{1}$ & $O_{1}$ & $X 2$ & $O_{2}$ \\
\hline $\begin{array}{c}\text { Kelas XI OTKP } \\
2\end{array}$ & $X_{2}$ & 02 & $X 1$ & 01 \\
\hline Sumber: & \multicolumn{4}{|c}{ Wallen } \\
\hline
\end{tabular}
(1993:253)

Keterangan :

$X_{1}=$ Penggunaan metode pembelajaran problem based learning $X_{2}=$ Penggunaan metode pembelajaran problem solving $O_{1,2}=$ Tes berfikir kreatif

Dalam

Counterbalanced Design ini menggunakan dua kelas dimana semua kelas merupakan kelas eksperimen. Perbedannya adalah terletak pada sub bahasan atau kompetensi dasar yang dilakukan disetiap kelas dengan berbeda treatment. Desain penelitian Counter balanced Design tidak menggunakan pre test tapi didalam desain ini siswa hanya diberi posttest saja sebagai tolak ukur keberhasilan pembelajaran.

\section{Uji Instrumen}

Dalam penelitian ini, perhitungan validitas dilakukan untuk validitas validitas item soal. Untuk mengukur tingkat validitas item soal, dengan menggunakan aplikasi SPSS versi 24. Kriteria validitas instrumen 
menggunakan korelasi item dengan korelasi total item. Dengan ketentuan jika P-Value $<0,05$ dikatakan valid, sebaliknya jika P-Value $>0,05$ dikatakan tidak valid (Kusnendi,2018). Untuk uji reliabilitas, Kusnendi (2017) menjelaskan bahwa: "... relates to the consistency of the measure(s)" (Hair, dkk., 2006: 104). Koefisien Cronbach's alpha merupakan ukuran reliabilitas internal (internal reliability) yang biasa digunakan dalam penelitian (Sekaran, 2000: 308). Kriteria minimal 0.70. The computation of Cronbach's alpha is based on the number of items on the survey $(k)$ and the ratio of the average inter-item covariance (c) to the average item variance ( $v$ ). Kusnendi (2008:96) koefisien alpha
Cronbach merupakan statisitk uji yang paling umum digunakan para peneliti untuk menguji reliabilitas suatu alat tes. Dilihat menurut statistik alpha Cronbach, suatu alat tes diindikasikan memiliki reliabilitas yang memadai jika koefesien alpha. Setelah melakukan uji validitas dan Reliabilitas, maka dilakukan analisis butur soal. Analisis butir soal bertujuan untuk mengadakan identifikasi soal-soal yang tergolong kelompok baik, kurang baik, dan soal yang jelek. Dengan analisis soal dapat diperoleh informasi tentang kejelekan sebuah soal dan petunjuk untuk mengadakan perbaikan. (Arikunto, 2013:222). Rekapitulasi hasil uji instrument tersaji dalam tabel berikut:

Tabel 3

Rincian Hasil Uji Coba Tes Kemampuan Berpikir Kreatif

\begin{tabular}{|c|c|c|c|c|c|c|}
\hline \multirow{2}{*}{$\begin{array}{l}\text { Butir } \\
\text { Soal }\end{array}$} & \multirow{2}{*}{ Validitas } & \multicolumn{2}{|c|}{ Reliabilitas } & \multirow{2}{*}{$\begin{array}{l}\text { Tingkat } \\
\text { Kesukaran }\end{array}$} & \multirow{2}{*}{$\begin{array}{c}\text { Daya } \\
\text { Pembeda }\end{array}$} & \multirow{2}{*}{ Keterangan } \\
\hline & & Nilai & Kriteria & & & \\
\hline 1 & Valid & \multirow{9}{*}{0,718} & \multirow{9}{*}{ Tinggi } & Mudah & Jelek & Tidak Dipakai \\
\hline 2 & Valid & & & Sedang & Cukup & Dipakai \\
\hline 3 & Valid & & & Mudah & Cukup & Dipakai \\
\hline 4 & Valid & & & Sedang & Cukup & Dipakai \\
\hline 5 & Valid & & & Mudah & Cukup & Dipakai \\
\hline 6 & Valid & & & Sedang & Cukup & Dipakai \\
\hline 7 & Valid & & & Sedang & Cukup & Dipakai \\
\hline 8 & Valid & & & Sedang & Cukup & Dipakai \\
\hline 9 & Valid & & & Sedang & Cukup & Dipakai \\
\hline
\end{tabular}


3. Hipotesis Penelitian

Siklus 1

Hipotesis 1

$H_{0}: \mu_{1}=\mu_{2} \quad$, tidak terdapat perbedaan rata - rata kemampuan berpikir kreatif siswa di kelas yang menggunakan metode pembelajaran Berbasis Masalah (problem based learning) dengan kelas yang menggunakan metode pembelajaran

Pemecahan Masalah (problem solving).

$H_{1}: \mu_{1} \neq \mu_{2}$; terdapat perbedaan rata - rata kemampuan berpikir kreatif siswa di kelas yang menggunakan metode pembelajaran Berbasis Masalah (problem based learning) dengan kelas yang menggunakan metode pembelajaran Pemecahan Masalah (problem solving).

\section{Siklus 2}

Hipotesis 2

$H_{0}: \mu_{1}=\mu_{2}$; tidak terdapat perbedaan rata - rata kemampuan berpikir kreatif siswa di kelas

yang

menggunakan metode pembelajaran Berbasis Masalah (problem based learning) dengan kelas yang menggunakan metode pembelajaran Pemecahan Masalah (problem solving).

$H_{1}: \mu_{1} \neq \mu_{2} ;$ terdapat perbedaan rata - rata kemampuan berpikir kreatif siswa di kelas yang menggunakan metode pembelajaran Berbasis Masalah (problem based learning) dengan kelas yang menggunakan metode pembelajaran Pemecahan Masalah (problem solving).

\section{Hasil Penelitian dan}

\section{Pembahasan}

\section{Analisa Hasil Pengolahan Data}

Dari hasil tes dan pengukuran dalam penelitian ini menghasilkan dua data yang terdiri dari dua variabel bebas dan satu variabel terikat. Yang menjadi variabel bebas dalam penelitian ini adalah metode pembelajaran Problem based learning dan Problem solving yang 
menjadi variabel terikat dalam penelitian ini adalah kemampuan berpikir kreatif siswa.

\section{Kemampuan Akhir Siswa}

Penghitungan nilai rata - rata dan simpangan baku merupakan langkah awal untuk pengujian selanjutnya. Pengujian rata - rata (mean) menggunakan data mentah dari hasil tes dan pengukuran untuk setiap variabel. Berikut ini adalah hasil perhitungan nilai rata - rata yang tertuang pada tabel di bawah ini.

\section{Tabel 4}

\section{Rata - rata Nilai Hasil Post Test}

\begin{tabular}{|c|c|c|c|c|c|}
\hline \multirow{2}{*}{ No } & Metode & $\begin{array}{c}\text { Nilai } \\
\text { Rata- } \\
\text { rata }\end{array}$ & Kelas & $\begin{array}{c}\text { Nilai } \\
\text { Rata-rata }\end{array}$ & Kelas \\
\cline { 3 - 6 } 1. & $\begin{array}{l}\text { Problem based } \\
\text { learning (PBL) }\end{array}$ & 72.2228 & OTKP-1 & 72.9178 & OTKP-3 \\
\hline 2. & Problem solving & 65.0464 & OTKP-2 & 66.4353 & OTKP-1 \\
\hline
\end{tabular}

Berdasarkan tabel di atas, terlihat perbandingan hasil post test dari metode dan kelas yang berbeda pada masing - masing pertemuan dimana untuk lebih jelasnya dapat disajikan melalui grafik berikut ini:

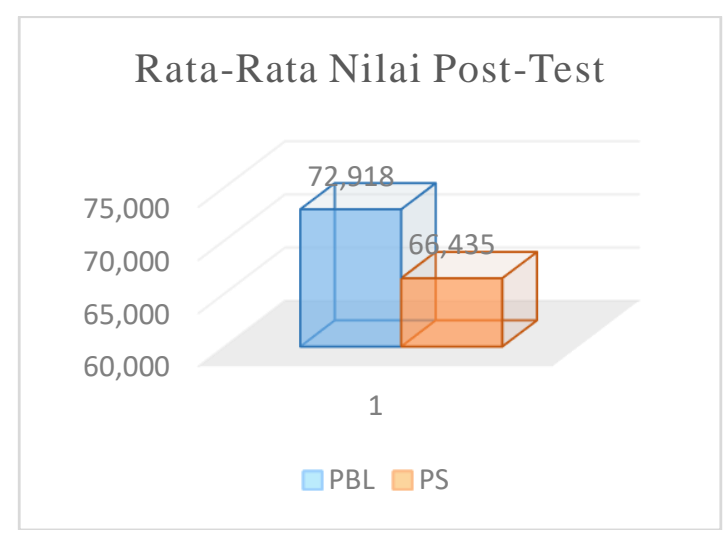

Gambar 2

Perbandingan hasil postest masing - masing kelas eksperimen

\section{a. Nilai Rata - rata pada Studi I}

Berikut ini adalah tabel bantu untuk membuat grafik berdasarkan hasil perhitungan nilai rata - rata yang diperoleh.

\section{Tabel 5 \\ Rata - rata Posttest pada studi I}

\begin{tabular}{|c|c|c|}
\hline $\begin{array}{c}\text { Jenis } \\
\text { Tes }\end{array}$ & Metode & $\begin{array}{c}\text { Rata }- \\
\text { rata }\end{array}$ \\
\hline \multirow{2}{*}{ Posttest } & $\begin{array}{c}\text { Problem based } \\
\text { learning }\end{array}$ & 72.2228 \\
\cline { 2 - 3 } & Problem solving & 65.0464 \\
\hline
\end{tabular}

Dari tabel 5 apabila dikonversikan ke dalam bentuk grafik atau diagram 3 yang disajikan sebagai berikut:

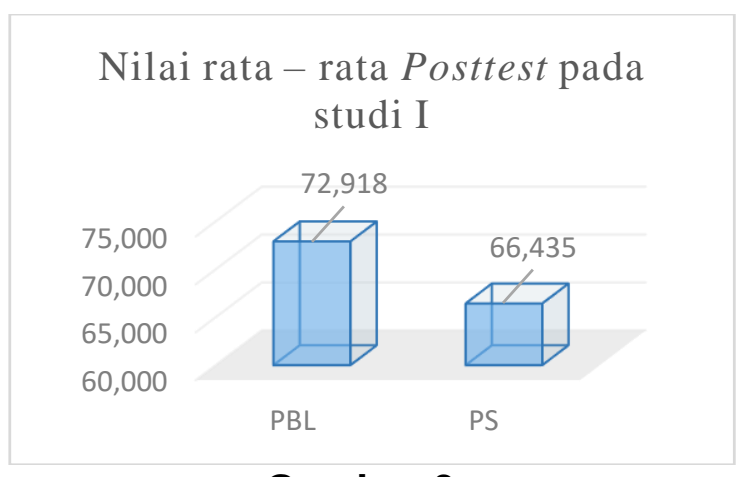

Gambar 3

Rata - rata Posttest pada studi I 
Hasil yang ditampilkan pada gambar 3 di atas menunjukkan perbandingan hasil rata - rata posttest terhadap kemampuan berpikir kreatif siswa dengan menggunakan tiga metode, diantaranya Problem based learning, Problem solving

Berdasarkan hasil posttest pada studi I di atas menunjukkan terdapat perbedaan dari setiap treatment yang dilakukan. Perbedaan point tersebut diantaranya dari metode Problem based learning ke Problem solving sebesar 7,17 Adapun urutan perolehan nilai rata rata tertinggi dari hasil posttest yaitu Problem based learning.

\section{b. Nilai Rata - rata pada Studi II}

Berikut ini adalah tabel bantu untuk membuat grafik berdasarkan hasil perhitungan nilai rata - rata yang diperoleh.

\section{Tabel 6}

\section{Rata - rata Posttest pada studi II}

\begin{tabular}{|c|c|c|}
\hline $\begin{array}{c}\text { Jenis } \\
\text { Tes }\end{array}$ & Metode & $\begin{array}{c}\text { Rata }- \\
\text { rata }\end{array}$ \\
\hline \multirow{2}{*}{ Posttest } & $\begin{array}{c}\text { Problem based } \\
\text { learning }\end{array}$ & 72.9178 \\
\cline { 2 - 3 } & Problem solving & 66.4353 \\
\hline
\end{tabular}

$$
\text { Dari tabel } 6 \text { apabila }
$$

dikonversikan ke dalam bentuk grafik atau diagram 6 yang disajikan sebagai berikut :
Nilai rata - rata Posttest pada studi II

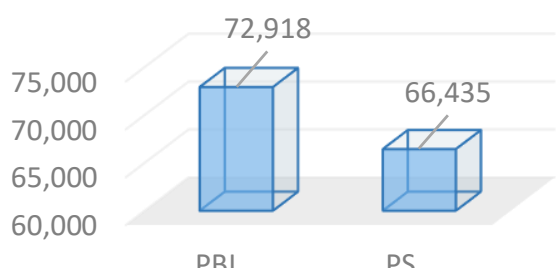

PBL

\section{Gambar 4}

Rata - rata Posttest pada studi II

Hasil yang ditampilkan pada gambar 4 di atas menunjukkan perbandingan hasil rata - rata posttest terhadap kemampuan berpikir kreatif siswa dengan menggunakan tiga metode, diantaranya Problem based learning, Problem solving.

Berdasarkan hasil posttest pada studi II di atas menunjukkan terdapat perbedaan dari setiap treatment yang dilakukan. Perbedaan point tersebut diantaranya dari metode Problem based learning ke Problem solving sebesar 6,48. Adapun urutan perolehan nilai rata rata tertinggi dari hasil posttest yaitu Problem based learning

\section{Uji Prasyarat}

\section{a. Uji Normalitas}

Pengujian distribusi normalitas dilakukan pada hasil test akhir yaitu hasil post test kemampuan berpikir kreatif. Pengujian normalitas ini digunakan untuk mengetahui apakah 
Didaktik : Jurnal IImiah PGSD STKIP Subang, ISSN Cetak : 2477-5673 ISSN Online : 2614-722X Volume V Nomor 2, Desember 2019

suatu data berdistribusi normal atau tidak. Pengujian normalitas ini menggunakan bantuan SPSS versi 24.0 dengan menggunakan taraf nyata $\alpha=0,05$.

Berdasarkan hasil pengujian normalitas dengan menggunakan bantuan SPSS versi 24.0 seperti pada tabel 7 di atas dapat disimpulkan bahwa seluruh data posttest berdistribusi normal ditunjukan dengan tingkat signifikansi lebih dari 0.05 dan dapat dijadikan prasyarat untuk analisis data uji t.

\section{b. Uji Homogenitas}

Pengujian homogenitas adalah sebagai syarat untuk pengujian hipotesis, karena dalam penelitian ini analisis data untuk menjawab permasalahan yang dimunculkan menggunaan uji perbedaan dua rata - rata (uji t). pengujian homogenitas menggunakan uji $F$ dengan formulasi yaitu membagi variansi besar dan variansi kecil. Untuk menguji homogenitas dapat dilakukan dengan cara membagi variansi besar pada hasil test akhir pada kelompok subjek dengan menggunakan metode Problem based learning (PBL) dan Problem solving

Berdasarkan hasil perhitungan menggunakan SPSS versi 24.0 seperti pada tabel 8 di atas, dengan demikian dapat disimpulkan bahwa seluruh data posttest berdasarkan pada tabel 8 di atas termasuk ke dalam kategori homogen atau memiliki varians yang sama sehingga dijadikan sebagai prasyarat analisis data uji t.

\section{Uji Hipotesis}

Fokus penelitian ini adalah untuk mengetahui perbedaan penerapan metode pembelajaran Problem solving, Problem based learning ( $\mathrm{PBL})$, dan Project based learning terhadap peningkatan kemampuan berpikir kreatif siswa. Dari fokus penelitian, rumusan masalah diuraikan menjadi 2 hipotesis yang merupakan jawaban sementara terhadap rumusan masalah. Analisis terhadap hipotesis penelitian dapat dilihat sebagai berikut.

\section{a. Hipotesis 1}

Untuk menguji hipotesis pertama tersebut, penulis menggunakan pendekatan statistik uji beda dua rata - rata (Independent Sample $t$-Test). Uji beda ini digunakan untuk mengetahui perbedaan kemampuan berpikir kreatif siswa di kelas yang menggunakan metode pembelajaran 
Didaktik : Jurnal IImiah PGSD STKIP Subang, ISSN Cetak : 2477-5673 ISSN Online : 2614-722X Volume V Nomor 2, Desember 2019

Problem based learning dengan yang menggunakan metode pembelajaran Problem solving pada studi I. Data yang digunakan untuk melakukan pengujian yaitu data hasil test akhir (posttest) dari kedua metode tersebut. Hasil perhitungan uji $t$ dengan menggunakan bantuan SPSS versi 24.0 dapat dilihat di bawah ini.

Tabel 8

Uji T Hipotesis I

\begin{tabular}{|c|c|c|c|c|c|c|c|c|c|}
\hline \multirow{3}{*}{ SIKLUS_1 } & \multicolumn{2}{|c|}{$\begin{array}{c}\text { Levene's Test } \\
\text { for Equality of } \\
\text { Variances }\end{array}$} & \multicolumn{7}{|c|}{ t-test for Equality of Means } \\
\hline & \multirow[t]{2}{*}{$\mathrm{F}$} & \multirow[t]{2}{*}{ Sig. } & \multirow[t]{2}{*}{$t$} & \multirow[t]{2}{*}{ Df } & \multirow{2}{*}{$\begin{array}{l}\text { Sig. } \\
(2- \\
\text { tailed })\end{array}$} & \multirow{2}{*}{$\begin{array}{l}\text { Mean } \\
\text { Diffe- } \\
\text { rence }\end{array}$} & \multirow{2}{*}{$\begin{array}{c}\text { Std. } \\
\text { Error } \\
\text { Differe } \\
\text { nce }\end{array}$} & \multicolumn{2}{|c|}{$\begin{array}{l}95 \% \text { Confidence } \\
\text { Interval of the } \\
\text { Difference }\end{array}$} \\
\hline & & & & & & & & Lower & Upper \\
\hline $\begin{array}{c}\text { Equal } \\
\text { variances } \\
\text { assumed }\end{array}$ & 0.08 & 0.76 & 2.19 & 70 & 0.03 & 7.17 & 3.26 & 0.66 & 13.69 \\
\hline $\begin{array}{c}\text { Equal } \\
\text { variances not } \\
\text { assumed }\end{array}$ & & & 2.19 & 69.37 & 0.03 & 7.17 & 3.266 & 0.65 & 13.69 \\
\hline
\end{tabular}

Berdasarkan hasil perhitungan menggunakan SPSS versi 24.0 seperti pada tabel 8 di atas diperoleh nilai sig $<\alpha$ yakni $0,031<0,05$ dengan demikian $H_{1}$ diterima. Hal ini menunjukkan bahwa hipotesis yang menyatakan "Terdapat perbedaan kemampuan berpikir kreatif siswa kelas XI OTKP-1 yang menggunakan metode pembelajaran Problem based learning ( $\mathrm{PBL}$ ) dengan kemampuan berpikir kreatif siswa pada kelas XI OTKP-2 yang menggunakan metode pembelajaran Problem solving pada studi I" diterima. Apabila dilihat dari hasil perolehan rata - rata (mean) kemampuan berpikir kreatif siswa yang menggunakan metode pembelajaran Problem based learning (PBL) sebesar 72,22 sementara nilai rata - rata (mean) kemampuan berpikir kreatif siswa yang menggunakan metode pembelajaran Problem solving sebesar 65,05 artinya nilai rata - rata posttest dari penggunaan metode PBL lebih tinggi dari nilai rata - rata (mean) kemampuan berpikir kreatif siswa yang menggunakan metode Problem solving. Maka dapat disimpulkan bahwa penerapan metode PBL lebih efektif dapat meningkatkan kemampuan berpikir 
Didaktik : Jurnal IImiah PGSD STKIP Subang, ISSN Cetak : 2477-5673 ISSN Online : 2614-722X Volume V Nomor 2, Desember 2019

kreatif siswa dibandingkan dengan metode Problem solving pada studi I.

\section{b. Hipotesis 2}

Untuk menguji hipotesis enam tersebut, penulis menggunakan pendekatan statistik uji beda dua rata - rata (Independent Sample t-Test). Uji beda ini digunakan untuk mengetahui perbedaan kemampuan berpikir kreatif siswa di kelas yang menggunakan metode pembelajaran Problem based learning dengan yang menggunakan metode pembelajaran Problem solving pada studi II. Data yang digunakan untuk melakukan pengujian yaitu data hasil test akhir (posttest) dari kedua metode tersebut. Hasil perhitungan uji $t$ dengan menggunakan bantuan SPSS versi 24.0 dapat dilihat di bawah ini.

Tabel 9

\section{Uji T Hipotesis 2}

\begin{tabular}{|c|c|c|c|c|c|c|c|c|c|}
\hline \multirow{3}{*}{ SIKLUS 2} & \multicolumn{2}{|c|}{$\begin{array}{l}\text { Levene's } \\
\text { Test for } \\
\text { Equality of } \\
\text { Variances }\end{array}$} & \multicolumn{7}{|c|}{ t-test for Equality of Means } \\
\hline & \multirow[t]{2}{*}{$F$} & \multirow[t]{2}{*}{ Sig. } & \multirow[t]{2}{*}{$t$} & \multirow[t]{2}{*}{ Df } & \multirow[t]{2}{*}{$\begin{array}{l}\text { Sig. } \\
(2- \\
\text { tailed) }\end{array}$} & \multirow[t]{2}{*}{$\begin{array}{l}\text { Mean } \\
\text { Diffe- } \\
\text { rence }\end{array}$} & \multirow[t]{2}{*}{$\begin{array}{l}\text { Std. Error } \\
\text { Difference }\end{array}$} & \multicolumn{2}{|c|}{$\begin{array}{c}95 \% \\
\text { Confidence } \\
\text { Interval of the } \\
\text { Difference }\end{array}$} \\
\hline & & & & & & & & Lower & Upper \\
\hline $\begin{array}{c}\text { Equal } \\
\text { variances } \\
\text { assumed }\end{array}$ & 5.35 & 0.02 & 4.97 & 70 & 0.00 & 19.21 & 3.86 & 11.51 & 26.92 \\
\hline $\begin{array}{c}\text { Equal } \\
\text { variances } \\
\text { not } \\
\text { assumed }\end{array}$ & & & 4.97 & 59.62 & 0.00 & 19.21 & 3.86 & 11.48 & 26.94 \\
\hline
\end{tabular}

Berdasarkan hasil perhitungan menggunakan SPSS versi 24.0 seperti pada tabel 9 di atas diperoleh nilai sig $<\alpha$ yakni $0,000<0,05$ dengan demikian $H_{1}$ diterima. Hal ini menunjukkan bahwa hipotesis yang menyatakan "Terdapat perbedaan kemampuan berpikir kreatif siswa kelas XI OTKP-3 yang menggunakan metode pembelajaran Problem based learning dengan kemampuan berpikir kreatif siswa pada kelas XI OTKP-1 yang menggunakan metode pembelajaran Problem solving pada studi II" diterima. Apabila dilihat dari hasil perolehan rata - rata (mean) kemampuan berpikir kreatif siswa yang menggunakan metode pembelajaran Problem based learning sebesar 72,92 sementara nilai rata - rata (mean) kemampuan 
berpikir kreatif siswa yang menggunakan metode pembelajaran Problem solving sebesar 66,43 artinya nilai rata - rata posttest dari penggunaan metode Problem based learning lebih tinggi dari nilai rata rata (mean) kemampuan berpikir kreatif siswa yang menggunakan metode Problem solving. Maka dapat disimpulkan bahwa penerapan metode Problem based learning lebih efektif dapat meningkatkan kemampuan berpikir kreatif siswa dibandingkan dengan metode Problem solving pada studi II.

\section{Analisa Efektivitas Penggunaan Metode}

Penggunaan metode pembelajaran memiliki kaitan dengan materi pembelajaran yang akan disampaikan. Materi pembelajaran memiliki tingkat kesulitan yang berbeda sehingga dibutuhkan teknik, metode, dan strategi yang relevan dengan karakteristik materi tersebut. Penggunaan metode pembelajaran yang relevan tentunya akan berbanding lurus dengan hasil belajar. Tentunya hasil belajar yang baik adalah kontribusi dari penggunaan metode belajar.

Analisis efektivitas penggunaan metode pada tiap studi yang telah dilakukan menunjukkan bahwa dengan menggunakan tiga kelas sebagai subjek dalam pembelajaran menampakkan bahwa efektivitas ketiga metode yang diterapkan memberikan pengaruh yang berbeda terhadap kemampuan berpikir kreatif siswa. Pada studi I dan II, selalu menunjukkan bahwa metode Problem based learning lebih efektif dari metode Problem solving. Hasil tersebut berdasarkan pada pengujian nilai rata - rata yang berasal dari nilai masing - masing setiap siswa melalui posttest yang telah diberikan. Berikut ini adalah gambaran hasil posttest dari setiap treatment yang telah dilakukan.

Tabel 10

Nilai Rata - rata Posttest Kelas Eksperimen

\begin{tabular}{|c|c|c|c|c|}
\hline & $\begin{array}{c}\text { SIKLUS } \\
1 \\
\end{array}$ & $\begin{array}{c}\text { SIKLUS } \\
2\end{array}$ & Total & $\begin{array}{l}\text { Rata- } \\
\text { rata }\end{array}$ \\
\hline PBL & 72,223 & 72,918 & 145,141 & 72,570 \\
\hline PS & 65,046 & 66,435 & 131,482 & 65,741 \\
\hline Total & 137,269 & 139,353 & & \\
\hline $\begin{array}{l}\text { Rata- } \\
\text { rata }\end{array}$ & 68,635 & 69,677 & & \\
\hline
\end{tabular}

Dari tabel 4.10 apabila dikonversikan ke dalam bentuk grafik dapat dilihat pada gambar 5 di bawah ini. 
Didaktik : Jurnal IImiah PGSD STKIP Subang, ISSN Cetak : 2477-5673 ISSN Online : 2614-722X Volume V Nomor 2, Desember 2019

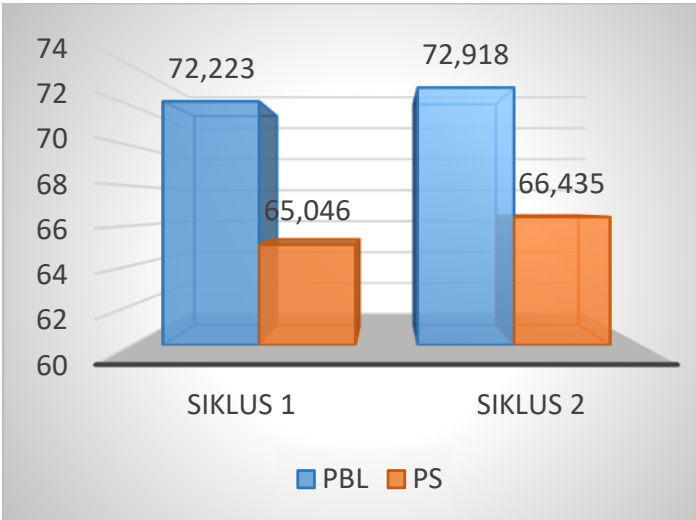

Gambar 5

Nilai Rata - rata dari Penggunaan Metode

Grafik 5 menunjukkan bahwa nilai dari metode Problem based learning selalu lebih tinggi di setiap studi dibandingkan dengan metode Problem solving, hal ini menyatakan bahwa Problem based learning konsisten di setiap studi.

Dari penerapan metode problem based learning dan problem solving di dua siklus yang telah dilakukan, didapatkan perbedaan nilai kemampuan berpikir kreatif siswa yang signifikan antara penggunaan metode Problem based learning dan problem solving. Hal ini sejalan dengan penelitian Magdalena (2014) yang melaporkan bahwa Problem based learning lebih efektif dalam meningkatkan kemampuan berpikir kreatif siswa. Hal ini dapat dilihat berdasarkan nilai rata - rata siswa pada studi I,II,dan III menunjukan hasil bahwa siswa yang menggunakan petode Pembelajaran Problem based learning diperoleh hasil sebesar 70.60, metode Problem solving sebesar 58.33. Dari rata rata tersebut telihat jelas bahwa terdapat perbedaan dari segi nilai rata - rata siswa cukup signifikan. Walau demikian, menurut Fadillah (2016) problem solving dapat digunakan sebagai alternatif dalam pembelajaran untuk meningkatkan kemampuan berpikir tingkat tinggi. Begitu juga Solihat menyebutkan bahwa metode problem based learning dan problem solving dapat dignakan guru dalam upaya meningkatkan berpikir kreatif siswa.

\section{Kesimpulan}

Secara umum, dari hasil penelitian dapat disimpulkan bahwa penerapan metode pembelajaran problem based learning lebih efektif dalam meningkatkan kemampuan berpikir kreatif siswa dibandingkan dengan metode belajar problem solving dan project based learning.

Secara khusus, berdasarkan rumusan masalah dan hipotesis penelitian yang diajukan serta hasil analisis data penelitian dan pembahasan yang dikemukakan, maka dapat ditarik kesimpulan bahwa 
terdapat perbedaan yang signifikan antara kemampuan berpikir kreatif siswa pada kelas yang menggunakan metode pembelajaran problem based learning dengan kemampuan berpikir kreatif siswa pada kelas yang menggunakan metode pembelajaran problem solving dimana kemampuan berpikir kreatif siswa pada kelas yang menggunakan metode pembelajaran problem based learning lebih unggul dibandingkan dengan kemampuan berpikir kreatif siswa pada kelas yang menggunakan metode pembelajaran problem solving. Hal ini menunjukan bahwa penggunaan metode pembelajaran problem based learning lebih efektif dalam meningkatkan kemampuan berpikir kreatif siswa dibandingkan dengan metode pembelajaran problem solving.

\section{DAFTAR PUSTAKA}

Arikunto, S. (2013). Prosedur Penelitian: Suatu Pendekatan Praktik. Jakarta: Rienaka Cipta.

Djamarah, S. B., \& Zain, A. (2013). Strategi Belajar Mengajar. Jakarta: Rineka Cipta.

Fadillah, A. (2016). Pengaruh Pembelajaran Problem Solving Terhadap Kemampuan Berpikir Kreatif Matematis Siswa. Fibonacci: Jurnal Pendidikan Matematika Dan Matematika, 2, 1-8.
Fakhriyah, F. (2014). Penerapan problem based learning dalam upaya mengembangkan kemampuan berpikir kritis mahasiswa. Jurnal Pendidikan IPA Indonesia, 3(1), 95-101. https://doi.org/10.15294/jpii.v3i1. 2906

Filsaime, D. K. (2008). Menguak Rahasia Berpikir Kritis dan Kreatif. Jakarta: Prestasi Pustakarya.

Fraenkel, J., Wallen, N., \& Hyun, H. (2011). How to Design and Evaluate Research in Education. Journal of American Optometric Association (Vol. 60).

Illeris, K. (2008). Problem solving. Journal of Workplace Learning, 15(2003), 4-7. https://doi.org/10.1108/13665620 310474615

Kusnendi. (2008). Model-Model Persamaan Struktural. Satu dan Multigroup Sampel dengan LISREL. Bandung: Alfabeta.

Lang, H. R., \& Evans, D. N. (2006). Metodes, Strategies, And Methods for Effective Teaching. USA: Pearson Education.Inc.

Lidinillah, D. A. M. (2013). Pembelajaran Berbasis Masalah (Problem Based Learning). Jurnal Pendidikan Inovatif, 5(1), $1-7$.

Mahmood, S. T., Jumani, N. B., \& Arshad, I. A. (2015). Problem solving method: A method for independent learning in mathematics. Hope Journal of Research, 2(4). Retrieved from https://www.researchgate.net/pu blication/274713189

Nizam. (2017). Penilaian untuk Pembelajaran Abad 21 Belajar 
dari berbagai hasil penilaian. Jakarta: Kepala Pusat Penilaian Pendidikan Badan Penelitian dan Pengembangan Kementerian Pendidikan dan Kebudayaan.

Purhantara, W. (2012). MENCIPTAKAN ORGANISASI YANG KREATIF Wahyu Purhantara. Economica: Review of Business and Economics Study, 8(2), 153-163. Retrieved from

http://download.portalgaruda.org/ article. .php?article $=52308 \& \mathrm{val}=4$ 73

Rofi'uddin, A. (2018). Model pendidikan berpikir kritis-kreatif untuk siswa sekolah dasar. Majalah Bahasa Dan Seni, 28(1), 72-94.

Solihat, A. N. (2017). Studi Komparatif Penggunaan Metode Pembelajaran Berbasis Masalah (Problem Based Learning) Dan Metode Pembelajaran Penyelesaian Masalah (Problem Solving) Dalam Meningkatkan Kemampuan Berpikir Kreatif Siswa. OIKOS: Jurnal Kajian Pendidikan Ekonomi Dan IImu Ekonomi, 1(2). https://doi.org/http://dx.doi.org/10 .23969/oikos.v1i1.236

Sugiyono. (2017). Metode Penelitian Kuantitatif, Kualitatif, dan R\&D (Bandung). Alfabeta.

Zubaidah, S. (2016). Keterampilan Abad Ke-21: Keterampilan Yang Diajarkan Melalui Pembelajaran. Seminar Nasional Pendidikan, 2(2), $\quad$ 1-17. https://doi.org/10.1021/acs.langm uir.6b02842 